\title{
Innovation and the commons: lessons from the governance of genetic resources in potato breeding
}

\author{
Koen Beumer ${ }^{1} \cdot$ Dirk Stemerding $^{2}$. Jac. A. A. Swart ${ }^{3}$
}

Accepted: 6 October 2020 / Published online: 15 October 2020

(c) The Author(s) 2020

\begin{abstract}
This article explores the relation between innovation and resources that are governed as commons by looking at the governance of potato genetic resources, especially in the context of the emergence of hybrid diploid potato breeding that will enable potato propagation through true seeds. As a new breeding tool, hybrid diploid potato breeding may not only revolutionize traditional potato breeding practices, it may also strongly affect current governance modes of potato genetic resources as a commons. Contrary to conventional accounts of the commons that treat technological innovation mainly as an exogenous factor, we argue that technological innovation can better be understood as an endogenous factor. In particular, we develop a co-production framework of innovation and the commons that draws attention to the different ways in which innovation, commons and its governance interact. Using this framework, we demonstrate that the constitution of potato genetic resources as a commons cannot be understood without considering the various ways in which technological innovation affects resources and mediate how these are governed. While reversely, technological innovations themselves are also enabled and constrained by users who govern potato genetic resources as a shared resource. We argue that changes in the governance of genetic resources can be understood as a change from one socio-technical constellation to another, whereby innovations, resources, and institutions are continuously co-produced.
\end{abstract}

Keywords Commons $\cdot$ Innovation $\cdot$ Genetic resources $\cdot$ Potato $\cdot$ Hybrid breeding $\cdot$ Co-production

\section{Introduction and background}

The governance of resources as commons is increasingly recognized as a feasible alternative to modes of resource governance characterized by dominating top-down governmental control or private ownership. Since the late 1980s, a burgeoning body of literature has emerged demonstrating the success and versatility of community governance of the commons (e.g. Ostrom et al. 1999; Stern et al. 2002; Laerhoven and Ostrom 2007). Besides the knowledge commons, however, the relation between the commons and innovation

Koen Beumer

k.beumer@uu.nl

1 Copernicus Institute of Sustainable Development, Utrecht University, Princetonlaan 8a, 3584 CB Utrecht, The Netherlands

2 Independent Researcher Biotechnology \& Society, Enschede, The Netherlands

3 Science and Society Group, University of Groningen, Groningen, The Netherlands has largely escaped attention-not only when it comes to the way innovation may impact the commons but also how resources for innovation can be governed as a commons. In a time when it has become increasingly clear that neither complete governmental control over innovation nor the laissez-faire economics of neoliberal markets are without problems, it is worth investigating the governance of commons as yet another institutional setting that may interact with innovation in diverse ways.

This article explores the relation between the governance of the commons and innovation by looking at potato genetic resources-a genetic resource that is key in potato innovation. Potato (Solanum tuberosum L.) is one of the world's most important food crops. Originally hailing from the Andes, potato is currently the fifth-largest crop in the world in production volume, after sugarcane, maize, wheat, and rice (FAO 2015), and is widely expected to gain an even more important role in the world's food supply thanks to its relatively healthy nutrient content, low water need, and its rather easy cultivation (Haverkort and Struik 2015). In the context of food security and the pursuit to realize the UN 
Sustainable Development Goals, sustained efforts are needed to breed improved potato varieties that are less susceptible to diseases, can be cultivated in new environments, and are more robust in the age of climate change (Haverkort and Verhagen 2008). However, developing new potato varieties has traditionally been a challenging and time-consuming process due to the complex genetic make-up of potatoes.

In recent decades, several technologies have been applied to potato breeding that promise to accelerate the process of unlocking the genetic diversity in potato, such as genetic engineering, molecular marker technology, cis-genesis, and more recently gene editing (Jansky et al. 2016; Bethke et al 2019). This article focuses on the governance of genetic resources in the context of another technological innovation: hybrid diploid potato breeding. This innovation makes it possible to propagate potatoes not only through tubers but also by true seeds, while maintaining genetic uniformity and preventing the transfer of diseases to the next generation. As $25 \mathrm{~g}$ of true potato seed is equivalent to 2.5 tonnes of seed tubers, this innovation may also significantly reduce transport costs. Moreover, whereas classical potato breeding needs several decades to develop a new variety, this new technology may reduce that to 3-6 years, accelerating the introduction of new varieties in agricultural practices enormously.

Hybrid potato breeding, however, may also affect traditional tuber propagation systems that govern the availability of genetic resource as a commons. In the Netherlands for example, a country that holds a share of over $50 \%$ of the world export of seed potato tubers (Rabobank 2016), potato genetic resources have traditionally been widely shared within the Dutch potato sector and are governed by a set of common rules regarding the use of these resources (Almekinders et al. 2014). In recent decades increasing commercialization of plant breeding and the advent of new biotechnologies as breeding tools have created tensions between traditional commons-based modes of governance and new forms of appropriation of genetic resources (Visser et al. 2019). As a new breeding tool, hybrid diploid potato breeding fits in this history, as it may not only revolutionize current breeding practices, but also affect the institutional constellations that govern potato genetic resources as a commons. Aiming at a more detailed understanding of the relation between the commons and innovation, this article therefore investigates how hybrid diploid breeding and the governance of potato genetic resources interact.

The next section provides a theoretical introduction for exploring the relation between the commons and innovation, followed by a further specification of the research questions that will guide the analysis in this article.

\section{Commons and innovation}

A commons refers to "a shared resource, co-governed by a community of users according to their rules and norms" (Bollier 2014). In a broad sense, commons can thus be understood as resources that are governed in a way that "exceeds the division between public and private" (Terranova 2015 , p. 9). For a long time the standard idea in economics was that commons, especially so-called common-pool resources that are depletable and widely accessible, are subject to the 'tragedy of the commons' (Hardin 1968). This so-called collective action problem builds upon the classical economic view of humans as self-interested individuals under the assumption that everyone will take what one can and that the resource will inevitably be depleted. The prevailing view hence was that only top-down governmental intervention or privatization could regulate or exclude common-pool resources from deterioration and depletion.

Since the 1980s a stream of literature with the late Nobel laureate Elinor Ostrom as one of the leading authors, has countered this view by demonstrating that such common-pool resources can be sustainably governed by communities themselves (e.g. Ostrom et al. 1999; Ostrom 2002, 2009; Stern et al. 2002; Laerhoven and Ostrom 2007). Based on hundreds of case studies in which communities successfully managed to govern their common-pool resources in a sustainable manner, they discovered institutional arrangements to counteract the problems of collective action without resorting to either top down governmental regulation or privatization. Rather, these arrangements come in many different forms and often slowly emerge over time through processes of collective learning. The prevalence of such hybrid arrangements of governing even has led some to argue that strong top-down governmental control, or privatization (turning resources into purely private goods, governed through market mechanisms) can be regarded as exceptions, and that hybrid forms of community-driven governance are the norm (WRR 2012).

Ostrom and colleagues drew upon elaborate empirical work to identify so-called design principles and institutional arrangements that appeared to be important in maintaining resources as a commons and to make these resources available and accessible to communities of users in a sustainable way (Ostrom 1990). These design principles particularly draw attention to the importance of institutional arrangements in maintaining a resource as a commons. They for example stress the relevance of defined boundaries and scales for the governance of resources and the communities involved, the need of appropriate monitoring, sanctioning and conflict resolution, and not 
in the least, the recognition of the role of the community by higher-level authorities. More generally, because institutional arrangements can impact the availability and accessibility of resources, it follows that a resource that is a public good under one institutional arrangement can be a common-pool resource (or a club good or a private good) under another institutional arrangement.

Plant genetic resources as a commons, whether seeds or genetic knowledge, have been extensively discussed from this institutional perspective. In particular, plant genetic resources for food and agriculture (PGRFA) have become a subject of global interest and international legal regulation, with the aim to increase their sustainable use and conservation and to promote equitable benefit sharing (Halewood et al. 2013). In this process there has been a shift in conceptualization from PGRFA as a global public good or 'heritage of mankind', available to everyone without restriction, to conceptualizing PGRFA as a commons, based on membership-related benefits and a collective management of resources by these members. Moreover, PGRFA have been characterized in this literature as a 'new commons' because of their partially human-made nature as a result of a long history of agriculture-related practices of seed selection, cross-breeding and conservation (Halewood 2013; Dedeurwaerdere 2012, 2013). In this context, the technological transformations of PGRFA, especially with the rise of digital sequence information, has provoked much discussion about its implications for the ownership and availability of resources and practices of access and benefit sharing (Aubry 2019; Halewood et al. 2018; Laird and Wynberg 2018; Scott and Berry 2016; Welch et al. 2017).

In conceptualizing the commons, we should therefore not only focus on the institutional conditions, but also on how the availability and accessibility of resources are mediated by technological developments. However, in the commons literature, technological innovation is largely treated as an exogenous variable that has little or no direct impact on the constitution of the commons itself. Apart from literature on the so-called knowledge commons (Hess and Ostrom 2006; Frischmann et al. 2014), only recently a number of studies have drawn attention to how technological innovation may affect the governance of commons. Such studies have for example shown how technological innovations may alter the conditions of exploitation of resources and thereby necessitate institutional changes for commons to be maintained (Wormbs 2011; Stern 2011).

Others have highlighted how technological innovation may itself become a resource that is being governed as a commons (Berge and Kranakis 2011; Wormbs 2011; Harvey and McMeekin 2010). The case of radio broadcasting frequencies is particularly illustrative, as this innovation was both a rivalrous resource (it only offered broadcasting space for a limited number of radio stations) and non-excludable (users could technically not be barred from attempting to broadcast at a particular frequency). This initially resulted in "chaos on the ether" (Wormbs 2011, p. 93) before institutions emerged for governing radio frequencies as a commons.

Inspired by these approaches we aim to conceptualize technological innovation as an endogenous variable in the constitution of the commons. In particular we will draw upon the framework of co-production of technology and society (Jasanoff 2004), an interpretative approach that emphasizes that technology and social order are strongly intertwined and are shaping each other. On the one hand this framework highlights that knowledge and technology are not neutral tools but are socially constructed in particular contexts, while on the other hand, it highlights that social order itself is also structured by scientific knowledge and technological artefacts. In short, as Jasanoff summarizes, "knowledge and its material embodiments are at once products of social work and constitutive of forms of social life" (Jasanoff 2004, p. 2).

From this perspective innovation in crop breeding is on the one hand considered as being dependent on governance arrangements in which genetic resources are made available through practices of collection, exchange, and conservation. Simultaneously however, on the other hand, it recognizes that genetic resources may become incorporated in innovations (like new crop varieties or other biomaterials) that in turn may strengthen or restrict the availability of these resources and thereby affect the social order of governing genetic resources as commons (Deibel, 2013). Innovations in crop breeding are hence impacted by institutional arrangements that govern resources as commons while simultaneously innovation impacts those institutional arrangements.

Contrary to conventional accounts of the commons, this perspective of social construction does not provide primacy to the nature of resources and the institutions that govern them independent from technologies and innovation (i.e. treating them as exogenous variables), but instead considers these resources and institutions as part of socio-technical constellations in which social order and technology are continuously intertwined and co-produced (Jasanoff 2004).

In what follows, we will use this co-production lens on the relation between the commons and innovation in a case study on potato breeding: we will describe how established arrangements of governing potato genetic resources interact with the emerging innovation of hybrid diploid potato breeding. Four research questions have guided us in this case study (Sects. 4.1-4.4):

1. How are potato genetic resources being governed in the Netherlands? To what extent and in what ways are these resources made available and accessible as a commons? 
2. How are the availability and accessibility of potato genetic resources as commons mediated by innovation in general?

3. Using the case of innovation in hybrid diploid potato breeding, how is this specific innovation in turn mediated by the availability and accessibility of potato genetic resources as commons?

4. What are the implications of hybrid diploid potato breeding as an emerging innovation for the availability and accessibility of potato genetic resources as commons?

\section{Methodology and sources}

With the aim to study the co-production of the commons and technological innovation, we have been seeking sources that can help to shed light on the nature of genetic resources, the institutional rules that govern them, and ongoing technological developments in the Netherlands and the wider potato world. We collected data in various ways. Firstly, academic and grey literature, describing genetic resources and/or innovation in the Dutch potato sector, was systematically gathered by using different search engines, by searching through organizational websites and reference lists, and by asking interviewees for valuable readings.

Secondly, semi-structured qualitative interviews were held with key stakeholders involved in the Dutch potato sector (Table 1), including breeding companies, amateur breeders, farmers, processing companies, researchers, policy makers and non-governmental organizations. A question list was prepared covering as much as possible aspects relevant to the governance of potato genetic resources and innovation. The interview guide began with broad questions about hybrid diploid potato breeding and the potential implications of this technology, then moved to more specific questions on topics like the accessibility and availability of potato genetic resources, the norms and rules governing those resources, and the stakeholders that impact and are impacted by those norms and rules. In conducting interviews, this list was not used as a straitjacket for the order of the questions but rather as a guidance and checklist for an otherwise open conversation that allowed the interviewees to speak frankly.

As an emerging and promising innovation hybrid diploid potato breeding is still developing and its impact is hence largely in the future. The potential implications of hybrid diploid breeding for the governance of potato genetic resources were therefore investigated by systematically mapping expectations among those stakeholders that are in the best position to judge about these futures (Beumer and Edelenbosch 2019). These expectations are salient not only because they shed light on how the possible socio-technical constellations for governing potato genetic resources may look like in the future. They are also relevant in that expectations about the future may have an effect on the present-i.e. they are performative and steer the behaviour of actors in anticipation of a changing future (Brown and Michael 2003; Borup et al. 2006).

Table 1 List of interviewed actors

\begin{tabular}{lll}
\hline Actor & Position & Date \\
\hline Start-up seed company & Head of research and development & 29 March 2016 \\
Start-up seed company & Agronomist & 14 December 2017 \\
Government ministry & Senior policy officer seeds and plant propagation material & 29 July 2016 \\
Inspection service & Director & 16 July 2016 \\
Amateur breeder & Also historian of Dutch potato breeding & 28 July 2016 \\
Seed tuber farmers & Farm owners & 28 July 2016 \\
Potato farmer & Organic farmer & 28 February 2017 \\
Gene bank & Curator potato collection & 26 February 2016 \\
Agricultural university & Emeritus professor of plant breeding, specialized in potato & 16 June 2016 \\
Agricultural university & Professor of plant breeding, specialized in organic potato & 18 May 2016 \\
Agricultural university & Professor of plant research, specialized in potato & 16 June 2016 \\
Agricultural university & Associate professor agricultural technology and social science & 2 July 2016 \\
Environmental NGO & Campaigner gentech and sustainable agriculture & 15 July 2016 \\
Development NGO & Programme coordinator soya and livestock & 3 March 2017 \\
Trading company & Breeder & 21 May 2016 \\
Trading cooperation & Director of research & 30 January 2017 \\
Strawberry trading company & Director & 1 December 2016 \\
Lobby organization & Director & 23 June 2016 \\
Processing industry & Director of breeding & 22 April 2016 \\
\hline
\end{tabular}


The combination of academic and grey literature, sector statistics, and qualitative interviews led to a rich body of sources that brought into view the evolving socio-technical constellations in the Dutch and wider potato world and it allowed information to be verified through triangulation. The findings and interpretations were further triangulated at various moments by using a panel of experts from the Dutch potato sector. This expert panel was part of our research project funded by the Dutch science foundation (NWO) and included key stakeholders from breeding companies, government, civil society organizations, regulatory agencies and universities. Several presentations on the topic of this paper were given during meetings of the expert panel with elaborate time for comments and discussions.

\section{Results}

\section{How are potato genetic resources being governed in the Netherlands?}

The Dutch potato sector can be divided into three main parts (see Fig. 1): trading companies that breed new varieties and produce seed tubers as starting material for cultivation (the breeding sector), farmers who cultivate, i.e. they vegetatively replicate these tubers and produce seed and ware potatoes for the market (multiplication and production sector), and companies that deliver potatoes to supermarkets for consumption or process them into products like fries or chips or starch (processing and retail sector). These sectors are supported, informed, and regulated by publicly funded research institutions, national and international agencies and policies, and by consumers and non-governmental organizations (Van Dijk et al. 2016).

Potato genetic resources are predominantly used for developing new varieties by so-called trading houses. These companies specialize in developing new varieties both for Dutch ware growers and for export markets worldwide of socalled 'seed potatoes' (which are actually tubers and should not be confused with true potato seeds). Five large trading houses take up most of the market in the Netherlands, and all trading houses together annually export over 800,000 tonnes of seed tubers, amounting to about $60 \%$ of the world's total potato export (Tönjes 2016).

Besides the trading houses, potato genetic resources are also used by amateur breeders, by scientists from public universities, and occasionally by the processing industry. The resources are governed by a set of practices, rules and norms that ensures that they are widely available and accessible to the breeders. Genetic resources are for example freely accessible, although bounded by a contract, through the Dutch gene bank, an institute specialized in maintaining genetic resources from around the world. Under the In Trust Agreements (ITAs) on acquisition and distribution of germplasm by institutes of the Consultative Group for International Agricultural Research (CGIAR), actors around the world can freely access genetic material held in international gene banks (Byerlee and Dubin 2010). Gene banks are therefore widely considered as key institutes in maintaining the accessibility of genetic resources (Galluzzi et al. 2016; De Jonge 2008).

Although the adoption of the Convention on Biological Diversity in 1992 has resulted in a virtual stop in the collection of new wild and local varieties, the Dutch gene bank has a large collection of material that was gathered prior to 1992 (interview 26 February 2017; see also Halewood et al. 2013). This gene bank is housed at Wageningen University and Research (WUR) and stores over 2800 potato populations. Research and maintaining the freezers and fields to preserve the collections are mainly funded by the government. Trading houses contribute $10 \%$ of the budget, in recognition of the value of free access to these materials (interview 26 February 2017). Trading houses further provide occasionally contributions in kind by multiplying gene bank populations to ensure their maintenance and accessibility (interview 26 February 2017).

Genetic resources are further made available and accessible through practices of sharing within the community of breeders of newly developed varieties. Access to competitors' varieties for breeding purposes is legally ensured through Plant Breeders' Rights (PBRs). Like patents, this form of property rights affords a temporary monopoly to
Fig. 1 The organizational landscape for potato breeding in the Netherlands (Van Dijk et al. 2016)
Policy and regulation

l

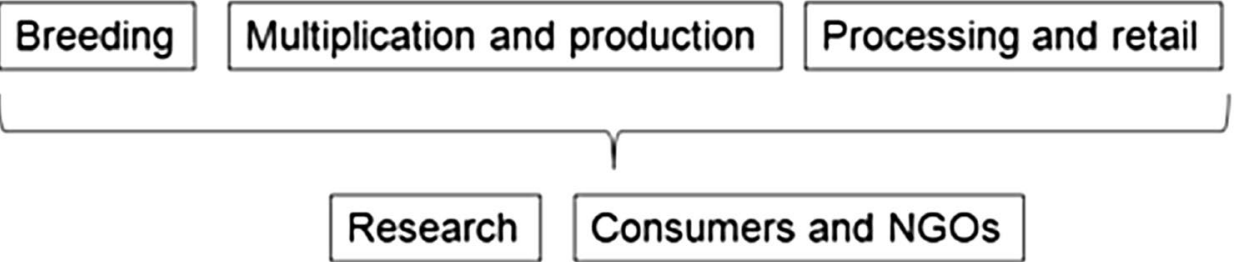


the breeder who has developed a new variety, thus providing an incentive for investing in innovative activities. Unlike patents, however, breeders' rights allow competitor breeders to use these varieties for the development of new varieties free of costs and rights. This, so-called breeders' exemption ensures that once a variety has been granted breeders' rights or released in the market, the genetic material is freely available for developing new varieties by others (Smith et al. 2016; UPOV 1991).

Breeders' rights are granted by (inter)governmental agencies, based on the guidelines of the International Union for the Protection of New Varieties of Plants (UPOV), an intergovernmental organization that was established in 1961. As of February 2020, the Union counts 76 members, including most Western countries, China and Russia, the European Union and the African Intellectual Property Organization. Its aim is to encourage the development of improved plant varieties through providing temporary property rights to breeders. The conditions for granting such rights are the novelty of a new variety, as well as its distinctness, uniformity, and stability (DUS criteria).

In the Netherlands the implementation of these rules is partly ensured by the Dutch General Inspection Service (abbreviated in Dutch as 'NAK'). This is a semi-governmental agency established in the early twentieth century when farmers and trading houses felt the need for a reliable quality standard that could help the export of starting material (interview 16 July 2016). The NAK plays a key role in the Dutch potato sector as it provides valuable quality marks to tuber batches and it collaborates with Dutch Food and Consumer Products Safety Authority ensuring compliance with sanitary and phytosanitary measures. The NAK also performs research to substantiate the granting of plant breeders' rights to new varieties by the Dutch Ministry of Agriculture.

In case of violation of plant breeders' rights, a resolution is initially sought amongst the conflicting parties, but parties can also go to court to stop presumed violation, charging to pay compensation for the damages and even occasionally putting criminal charges for serious violations of the rights (Agentschap 2011). The value of maintaining plant breeders' rights is widely recognized by the trading houses, who have long taken a dismissive stance towards patenting of plant genetic material, as this would obstruct the wide availability of genetic resources.

In practice the sharing of potato genetic resources goes even further. For instance at periodic farmers' markets, where breeding houses display their latest work, it is common practice to share both the information and genetic material with competitors well-before breeders' rights are obtained (interview 29 July 2016). While breeders thus may disclose valuable information and resources to their competitors, they also stand to the benefit from learning about the developments made by others.

The sector-wide practice to share genetic material is also illustrated by the collaboration of the trading houses with collectives of so-called amateur-breeders: experienced potato farmers with a passion for potato breeding and a keen 'breeders' eye', who help breeding companies in selecting favourable and strong plants in the field that are suitable for further breeding. These farmer-breeders receive potato tubers from the trade companies and work on a no-cure nopay basis, receiving income only after a variety that they helped to develop is registered and marketed. Depending on the contract, license fees are then divided between the farmer-breeder and trading house (Lammerts van Bueren and van Loon 2011). However, if one of these farmer-breeders breaks the contract and shares genetic material entrusted to them by the trading houses with outsiders there are severe sanctions (interview 28 July 2016; interview 30 January 2017). This collaboration between trading houses and collectives of farmer-breeders is a rather unique feature of the Dutch potato breeding sector (Almekinders et al. 2014). As a collaborative and rather open practice of potato breeding it resembles the concept of 'collective invention' (Allen 1983), which is characterized by incremental improvements, the sharing of information, and by being embedded in practical experience.

Nevertheless, there are clear boundaries to these sharing practices. Interviewees for instance made it clear that breeding information and materials are only shared amongst breeders within the Netherlands, given past incidents whereby genetic material was obtained by people from countries where it is nearly impossible to monitor whether plant breeders' rights are respected, and where varieties may be marketed as their own (interview 30 January 2017). Moreover, very strict phytosanitary measures create major obstacles to the import of potato genetic materials from outside the European Union, which means that the circulation of such materials remains limited mainly to breeders within EU countries (personal communication Dutch potato breeder 2020).

Our discussion of the governance of potato genetic resources shows how these resources, through both formal institutional arrangements and informal practices, are made widely available and accessible to the community of breeders in the Dutch potato sector. Thus, in terms of Ostrom's design principles, we can conclude that in the Netherlands these genetic resources are maintained as a commons, characterized by clearly defined boundaries, rules regarding the appropriation and provision of resources (including ITAs, PBRs and mutual obligations between trading houses and farmer breeders), informal practices of sharing and collaboration, and mechanisms of conflict resolution, using a scale of graduated sanctions through a semi-autonomous agency, 
indicating that higher-level authorities recognize the selfdetermination of the community (see Ostrom 2009).

\section{How are potato genetic resources as commons mediated by technological innovation?}

Thus far, we focused in our discussion of the Dutch potato sector on the institutional arrangements that are important in maintaining genetic resources as a commons. However, the co-production framework suggests that the possibility to use potato genetic material for breeding new varieties does not only depend on the institutional availability and accessibility of these materials, but increasingly also on techno-scientific knowledge and skills that enable breeders to unlock genetic material as a new resource. In the case of potato, this is a particularly challenging process. Conventional breeding proceeds by crossing two parent plants each with desirable traits. In potato, such crosses produce highly heterogeneous offspring because of the potato's tetraploid genome. It is not uncommon for breeders to start with several hundreds of thousands of seedlings per crossing, which are then brought down to a few varieties by selecting the best contenders every growing season. This requires very particular skills and the entire process can take up to several decades.

The gene bank is particularly illustrative of the fact that the institutional availability and accessibility of genetic resources does not automatically mean that these resources can easily be unlocked. The available resources at the gene bank largely consist of seeds from wild relatives of the cultivated potato, which are valued for the possible presence of traits that cannot be found in cultivated potato varieties. But these potato species often are highly heterogeneous. For example, a species containing a wanted resistance gene may simultaneously be small, bumpy, and sour-traits that must be eliminated through a lasting breeding process. As in many other crops, isolating valuable potato genetic material from wild plants thus requires a collective and highly time-consuming effort. However, the efforts through which these genetic resources can be unlocked are also founded on an increasing scientific understanding and technological control of potato genetics. Whereas breeders traditionally need to rely on their breeders' eye to select plants with desirable traits, innovation in biotechnology and genetics makes it possible to shift the selection process from the phenotype to the genotype, i.e. from the plant in the field to the DNA in the plant, which increases the speed and precision of breeding. Large breeding companies with their own molecular labs now extensively use genetic marker technology for identifying plantlets with favourable genes.

To stimulate the development and sharing of new knowledge, skills and materials that may help to unlock potato genetic resources, the Dutch government undertook occasional attempts to strengthen collaboration between universities and trading houses by providing partial funding for initiatives that may not have been feasible for single companies or farmer-breeders to organize. For example, over the last two decades, the Ministry of Economic Affairs initiated two large research projects to develop potato varieties that are resistant to late blight, a disease that is a major culprit to potato growers around the world (Haverkort et al. 2009; Lammerts van Bueren et al. 2008; Lammerts van Bueren and Hutten 2012). The importance of such practices of collaboration and sharing is widely acknowledged by both the public and the private sector and is generally seen as a key ingredient in the success of the Dutch potato sector worldwide.

To be sure, in the past the government took responsibility for such 'pre-breeding' activities through the public funding of plant breeding research, but gradually retreated from this responsibility, shifting breeding activities from the public to the private domain. However, instead of funding research that can subsequently be appropriated by private parties, as is the case in many other contemporary public-private research partnerships (e.g. Mirowski 2011), contemporary collaborations in Dutch potato breeding proceed under the condition that all trading houses which participate in the research process will continue to have access to the newly unlocked genetic material, thereby ensuring the availability and accessibility of this material as a commons.

Not all technological developments were institutionally embedded in ways that unambiguously strengthened the commons, however. With the rise of genomics as a new innovative field of research, the Dutch government likewise funded public-private partnerships focusing on 'precompetitive' research, including the Centre for BioSystems Genomics (CBSG, 2002-2012) which had the aim to unravel the genetic code of the potato and other agricultural crops. In this role the CBSG was involved in the international initiative of the Potato Genome Sequencing Consortium, providing a public platform which makes potato sequence data accessible to the scientific community at large (PGSC 2011). In the context of genomics innovation however, the support of public-private partnerships by the Dutch government went hand in hand with the promotion of intellectual property rights by patenting, reflecting a more general trend in plant biotechnology, genomics and commercially driven plant breeding, and also raising the question how to balance protection with sharing for the common good (De Jonge 2008; Kloppenburg 2004; Jefferson et al. 2015; Bonny 2017). This tension between unlocking and appropriating genetic resources also recurs in the governance of the new informational and molecular genetic capacities embodied in the growth of digital sequence information (Visser et al. 2019). Whereas the CGIAR global governance system of gene banks traditionally focuses on genetic materials as physical resources, the growing pool of digital sequence 
information creates new governance challenges requiring a tailored 'new commons' approach, to be adjusted to the 'dematerialized' status of genetic resources (Aubry 2019; Halewood et al. 2018).

These developments illustrate the relevance of our coproduction perspective, according to which potato genetic resources are constituted as a commons through continuous interactions between institutions governing it and technological innovations affecting the availability and nature of these resources. Indeed, contemporary practices of potato breeding cannot be understood apart from the role of various technologies, including high-tech genomics tools as well as more mundane technologies. Thus, conventional breeding practices, that work with several hundreds of thousands seedlings per crossing as genetic starting material, are aided by specially fine-tuned tractors for planting the seedlings; the genetic traits that trading houses and farmer-breeders select for are informed by the requirements of the processing machines used by potato chips factories (interview 22 April 2016); and even the freezers used to store genetic resources in the gene bank are themselves a technology that enables and constrains the way the commons can be governed (Radin and Kowal 2017).

By the same token, the perspective of co-production can also help us to understand several developments that put pressure on the commons, like the reorientation of governmental programs promoting pre-competitive breeding and the restrictions for worldwide circulation of wild varieties following the adoption of the Convention on Biological Diversity. Whereas conventional accounts of the commons would describe these developments primarily as institutional changes in the governance of the commons, from a co-production perspective these developments should be understood as changes driven by the interaction between governance arrangements and technological innovation. For instance, the expectation that countries could earn money from genetic resources over which the Convention on Biological Diversity gave them sovereign rights, which subsequently led to a steep drop in the free donation of novel wild varieties, cannot be understood apart from advances in biotechnology that enabled new forms of unlocking genetic material. Just because these technological advances promised novel ways to extract value from biological material, especially in the pharmaceutic sector, countries did change the practices and institutions for maintaining genetic resources as a commons.

\section{The case of hybrid diploid potato breeding: genetic resources as a commons}

The co-production perspective thus allows us to see that the constitution of potato genetic resources as a commons cannot be understood without considering the various ways in which technological innovations mediate - enable and constrain - how resources are governed and unlocked. Reversely, the co-production perspective also suggests that innovations themselves are enabled and constrained by the context in which they are developed, in this case one where a community of users governs potato genetic resources as a shared resource.

In this section we discuss hybrid diploid potato breeding as a case, with the aim to show more in detail how in (Dutch) potato breeding innovation is mediated by genetic resources as a commons. A first step in hybrid breeding is repetitive self-fertilization of plants ('inbreeding') in order to create 'homozygous' offspring lines. Within these lines the homologous chromosomes, originating from the male and female parent, are identical. The next step is to make crossings between different well-characterized homozygous (parent) lines, by which specific genetic features can be precisely and quickly combined into new 'hybrid' varieties. In the twentieth century the principles of hybrid breeding have been applied to an increasing number of crops like corn, rice, sugar beet, and tomato, and the technology was one of the key innovations driving the Green Revolution (Duvick 2009).

However, until recently, hybrid breeding was not practical in potatoes because the cultivated potato genome is tetraploid, meaning there are four homologous chromosomes instead of two, making the creation of homozygous inbred lines highly difficult and time-consuming. A possible approach would be to move to diploid potatoes, but these are self-incompatible, i.e. they have a mechanism that prevents self-fertilization and therefore inbreeding. Yet, in the past ten years, the Dutch start-up potato seed company Solynta (solynta.com: see also Table 1) has succeeded in developing a diploid hybrid potato breeding program by overruling this self-incompatibility in diploid potato plants (Lindhout et al. 2011). As authors of this article, we were in the position to closely follow the development of this innovation for several years through a collaborative project with this company, aiming to investigate strategies for responsible innovation in Dutch potato breeding (POTAREI 2015-2020).

This innovation of using self-compatible diploid potatoes to create hybrids is described both by outside observers and the company itself as a "revolutionary technique" and a "paradigm shift" in potato breeding (interview environmental NGO 15 July 2016; Solynta 2016; Beumer and Edelenbosch 2019). The innovation is expected to increase the precision and speed of breeding as well as to enable the propagation of potatoes through hybrid seed instead of tubers, thus preventing the transfer of tuber-bound diseases and strongly reducing transport costs (Lindhout et al. 2011; Stokstad 2019).

The development of this new innovation in potato breeding may not only help to unlock the large genetic variety of potato as a resource, it is also highly dependent on 
the availability and accessibility of these potato genetic resources as a commons. For example a key step in developing this innovation was making use of diploid germplasm. This was made available by a pre-breeding program from Wageningen University and is available as well from potato gene banks and other public research institutes (Lindhout et al. 2018; see also Lindhout et al. 2011). Another key step was to overrule self-incompatibility of potato plants, which was again based on a freely available genetic resource. Already in the late 1990s and early 2000s, researchers in Japan reported on a gene that could render diploid potatoes self-compatible (Hosaka and Hanneman 1998). This socalled Sli gene originates from a wild potato variety that is widely distributed in the Andes. Although this genetic material currently falls under the 1992 Convention on Biological Diversity and hence can no longer be accessed without prior agreement from national governments, it is available from international gene banks and also circulating among researchers and companies worldwide. Thus it was donated to Solynta's researchers by one of the Japanese authors of the 1998 paper on the Sli gene (Lindhout et al. 2011). Without the public and worldwide availability and accessibility of these crucial resources, it seems highly unlikely that Solynta's innovation could have been developed in its current form.

It was highlighted in the previous section that the constitution of potato genetic resources as a commons does not only depend on the institutional availability and accessibility of these resources but also on the skills, knowledge, and technologies required for unlocking genetic material. This is also the case with the development of hybrid potato breeding, as key steps in the development of hybrid true seed potatoes are enabled by skills, knowledge, and technologies that were previously made widely available (see for example the CGIAR Generation Challenge Programme). One example are molecular 'markers'- specific sequences of DNA - which can be used to identify the presence of particular genes in the plant. In the context of hybrid breeding markers are used to test the level of homozygosity in inbred parent lines and molecular markers can also be used to select parent lines for particular beneficial (combinations of) genes or to predict more accurately the breeding value of these lines. Furthermore, although the library of inbred parent lines developed by the Solynta company may already harbour many important traits for potato breeding, new favourable traits can be introduced into these lines by so-called marker-assisted introgression breeding. To this end, parent lines are crossed with a diploid potato plant carrying a specific gene of interest. In the subsequent selection process parent lines containing this gene can be identified with the help of molecular markers at an early stage of growth, thus significantly increasing the precision and speed of breeding. In this way, the Solynta company successfully introduced, within a couple of years, pest resistance genes in their experimental hybrid varieties (Lindhout et al. 2018).

Molecular markers were hence crucial to the development of hybrid potato breeding, yet the availability of these tools in general, and the genetic knowledge necessary to employ them, have been the result of public-private initiatives like the Potato Genome Sequencing Consortium. These projects made genetic maps and full genomic sequences publicly available as tools enabling the identification, mapping, isolation and functional analysis of useful genes (Lindhout et al. 2011). As an international group of public and private sector scientists noted, by "reinventing the potato crop at the diploid level", hybrid potato breeding enables breeders "to take full advantage of the modern genetics and genomics tools available to improve gain from selection" (Jansky et al. 2016, p. 2). Indeed, the wide availability and accessibility of genomic information and tools are crucially important for the power, precision and speed of hybrid breeding technology, as the use of markers clearly show.

\section{Implications of hybrid breeding for the governance of potato genetic resources}

In the previous sections we argued that the governance of potato genetic resources as a commons is mediated by technological innovations, and that innovations like hybrid diploid breeding, in turn are mediated by both genetic resources and techno-scientific knowledge and skills governed as a commons. In this section we move back again the co-production swing and explore how hybrid breeding-itself enabled by the genetic resources commons-may produce changes in the governance of potato genetic resources. As we have seen above, hybrid potato breeding is expected to be a "game changer" (interview government 29 July 2016; Stokstad 2019) that could potentially "change the power balance in the entire sector" (interview environmental NGO 15 July 2016). In other words, the introduction of hybrid potato breeding should be seen as a process of social-technical change that also may have implications for the governance of potato genetic resources as a commons. However, as the development of this innovation is still in its infancy, our discussion below of the changes it could bring will necessarily be mostly forward-looking and explorative.

In crops like maize, tomato, and sugar beet, the shift from conventional to hybrid breeding has historically been associated with increasing protection and corporate appropriation of knowledge and commercial marketing of seeds around the world. As a result of this process of commodification, farmers have gradually lost control over their seeds (Kloppenburg 2004; Borowiak 2004; Deibel 2013; Bonny 2017). Although this development is far from unique for hybrid breeding, hybrid crops afford breeding companies a special in-built economic protection. As seeds from hybrids will 
lose their uniformity and vigour, farmers cannot use them for the next growing season and have to buy new hybrid seeds every season (Brown and Caligari 2008).

Hybrids enable a company to apply a 'natural patent', so to say. For potatoes, however, this is not strictly the case, because this crop can be propagated vegetatively. Farmers can therefore simply multiply hybrid potatoes by planting the tubers they have produced from the seeds. These tubers will produce completely identical progeny, hence maintaining the desirable traits of the hybrid variety. Nevertheless, farmers who would like to grow hybrid potatoes will still be advised, just as with the conventional tuber-based system, to regularly buy new seed as tuber-based reproduction may stack diseases in subsequent generations, resulting in lower yields.

Hybrid breeding may, however, affect the availability and accessibility of potato genetic resources to breeders. When hybrid diploid potato varieties become available on the market, they will in principle be accessible to other breeders who are allowed to use these varieties for further breeding under the breeders' exemption. And as it is widely expected that hybrid breeding will enable genetic material to be unlocked with more power, precision and speed, it may result in a higher turn-over of potato varieties and the use of more 'distant' genetic resources in breeding. Thus, it may enhance the availability of potato genetic material which can also be readily used by competing hybrid potato breeders to improve their own diploid parental lines. But it will not be directly available for improving conventional tetraploid varieties. Conventional breeders first need to turn a hybrid diploid variety into a tetraploid variety by duplicating the chromosomes through a demanding technical procedure before it can be crossed with their tetraploid material. Therefore hybrid diploid varieties will be less accessible as a genetic resource for breeders traditionally working with tetraploid potato crops.

At first sight, the potential implications of hybrid diploid potato breeding for the governance of genetic resources thus seem to be fairly limited and mixed. It may first of all lead to a further unlocking of potato genetic resources that will become available in improved varieties. Farmers may profit from these varieties and may still propagate, share or trade the seed in the form of tubers. Breeders may use these varieties for further breeding based on the breeders' exemption, but for conventional potato breeders this might be technically more challenging, if not prohibitive. In other words, as a new innovation hybrid diploid potato breeding may affect the accessibility of genetic resources both positively and negatively, whereby the impediments are rather technical than institutional.

In one respect, however, the introduction of hybrid breeding entails a crucially important institutional change in the governance of potato genetic resources. Companies involved in hybrid breeding have to make huge investments in the development of inbred (parental) lines as the main building blocks for their own business. In a fully developed hybrid system, new varieties may be produced rather rapidly, but the creation of a sufficient collection of homozygous parental lines is a highly expensive and time-consuming process. Indeed, as a start-up company, Solynta was able to register its first hybrid variety only after 15 years of R\&D (personal communication Solynta breeder). Hybrid breeding firms, therefore, generally consider parental lines as their main economic asset and, accordingly, the Solynta company has taken strict measures to ensure that access to their parental lines is restricted, keeping them carefully secret from the breeding community. As we have seen, in conventional practices of Dutch potato breeding sharing is the rule, even including the informal exchange of breeding materials with potential economic value. However, whereas conventional breeders may safely exchange such materials knowing that it will take a long and uncertain effort to include these materials in new varieties, it would take competitors only a few years to develop new hybrid varieties, if they could indeed freely obtain mature parental lines as breeding material. Hybrid breeders are hence likely to think twice before sharing such genetic material.

The role of patents further demonstrates how the new importance of parental lines may change the governance of potato genetic resources as commons. As a new category of highly valuable potato genetic material, one way to protect these parental lines is patenting. Initially the Solynta company indeed sought to ensure profitability from its large investments in a hybrid breeding program by filing a patent on the technology used to create inbred parent lines. In this context, it made serious efforts to make other actors enthusiastic about hybrid breeding, also sharing information about the technology to other breeding firms (Beumer and Edelenbosch 2019). However, while a patent has been granted to the company in a number of countries outside the European Union, in Europe their patent application remained unsuccessful because of the new EU patent regulation that puts a ban on patents concerning natural materials and the materials to produce them (interview seed company 14 December 2017; European Patent Office 2017). Now that the technology can no longer be patented in the EU, the company is more reticent to share information about how to create a diploid hybrid potato breeding program. Although the company has shared information about its R\&D activities in a number of scientific publications, it will not go into much further detail in their communication and contacts about its breeding program, while keeping secret its parental lines (interview seed company 29 March 2016). Indeed, as a representative from a Dutch potato trading cooperation noted, informal requests for information and material, which in the Netherlands are very common among conventional 
potato breeders, are now considered by the Solynta company only on the condition of signing a confidentiality statement (interview trading cooperation 30 January 2017). Thus, the paradoxical outcome of the European ban on patents might be that it may actually have become harder for potato breeding companies to get access to the technology for hybrid breeding.

What future developments can we envisage for hybrid potato breeding in this context, and what could be the implications of these developments for the governance of genetic resources? As hybrid breeding is further getting off the ground, potato breeders may more and more compete on the basis of proprietary parental lines, considering their lines as a trade secret and probably also applying for patents on genetic traits that may further limit the access to genetic materials (Louwaars 2018). This may thus result in high entry barriers for newcomers in the field. As the ownership of such precious parent lines has high economic value, hybrid potato breeding might lead to a series of mergers and acquisitions in the potato value chain, akin to the mergers and acquisitions previously witnessed in the seed sector of other crops (Bonny 2017; Duvick 2009). Pushing the argument further, this could create a situation where a handful of corporate seed players gains sufficient size and capital needed to privately undertake the large-scale research efforts that currently still require commons-based collaboration and government coordination. This is in line with Allen's (1983) suggestion that traditions of collective invention disappear when costs of innovation rise in the context of the rise of costly R\&D facilities, knowledge protection, and the appearance of big companies.

Clearly, this is not to say that hybrid breeding necessarily (and only) results in private enclosure of potato genetic resources. The parental lines also create opportunities for new sharing arrangements, for example, and several institutions and practices for doing so are already emerging. The earlier mentioned developments in the field of genomics may, for example, strengthen an innovation dynamic in which genetic maps, sequences and markers are widely shared, enabling breeders to target valuable genes in available conventional or hybrid potato crops, and to incorporate these genes in their own varieties. As a result, modern breeding, including hybrid breeding, may increasingly require the establishment of new collaborations, combining the skills of the breeder with the in-depth knowledge of plant scientists and geneticists (Lindhout et al. 2018; Jansky et al. 2016; Halewood et al. 2018). As we described earlier, in conventional potato breeding the breeders' eye was of crucial importance in selecting the right varieties from a huge stock of plants, a skill that is mostly possessed by experienced potato farmers, and that has resulted in various collective sharing arrangements between farmer-breeders and breeding companies. Such traditional practices of sharing within the community of potato breeders may now, however, lose significance. Instead, hybrid potato breeding may lead to new sharing arrangements, drawing new actors in the commons, while excluding more traditional ones.

It is in this context, that the Solynta company, in stark contrast with its policy of keeping secret parental lines, recently took the step to release a complete genome sequence of one of its highly homozygous parental lines which, under specific conditions, is made available for the research community, together with the relevant plant material (Solynta 2019). The sequencing was done in collaboration with the department of Plant Breeding at Wageningen University $\&$ Research (WUR) and partly financed by PepsiCo. The company expects that through this public-private partnership, useful potato genetic traits will be explored and utilized more widely and quickly, taking full advantage of the hybrid breeding technology and contributing to a more sustainable potato production.

\section{Discussion}

In the foregoing, we have demonstrated that technological innovation can best be understood as an endogenous variable that not only affects the commons and its governance but that, reversely, is also shaped by the commons and its governance. Using this perspective, we have been able to foreground the complex interaction between the governance of potato genetic resources in the Netherlands, and the innovation of hybrid diploid potato breeding.

This perspective also enables us to identify several normative issues that emerge from the co-production of hybrid potato breeding and the governance of potato genetic resources, which we would like to turn to now. In our analysis, we identified a potential tension between two different kinds of dynamics, i.e. between corporate-based and commons-based modes of governance of genetic resources, which may both shape the future of hybrid potato breeding. The first mode of governance is driven by marketbased forms of research and protection of potato genetic resources and by corporate consolidation of hybrid diploid breeding - as we have seen for example in the tendency to keep parental lines secret. The second mode of governance is instead driven by the sharing of knowledge and materials, and by collaboration to strengthen the knowledge base for unlocking potato genetic resources through hybrid breeding - as is illustrated by the recent release of a complete genome sequence of one of the parental lines of the Solynta company.

This tension between corporate- and commons-based modes of governance also raises normative questions about the goals that are pursued in breeding, especially in relation to the Sustainable Development Goals (SDGs), as the 
two modes of governance have different implications for the potential contribution of hybrid potato breeding to the SDGs. Advocates of both modes of governance argue that hybrid potato breeding can positively contribute to global food security and more climate resilient agriculture, as hybrid potato breeding programs can increase the speed with which the "tremendous wealth of germplasm" can be unlocked (Lindhout et al. 2018, p. 103). For example, the Solynta company mentions on its website the potentially important role for hybrid diploid potato breeding in advancing a number of SDGs. Literature about potato farming in Africa, however, has clearly shown that innovative technologies often do not fit to poor farmers' reality (Gildemacher et al. 2009) and that the introduction of high quality seeds often fails to address the needs of many resource-poor smallholder farmers in developing countries (Almekinders et al. 2019). In response to this mismatch other innovation strategies have been proposed, emphasizing the need to strengthen traditional farmers' practices of seed saving and exchange and advocating participatory plant breeding as a strategy that may effectively support the maintenance and improvement of crop genetic diversity by smallholder farmers (Almekinders et al. 2008).

The message we can take from this discussion is that we cannot leave the development of hybrid potato breeding to corporate-based governance only. In order to fully reap the benefits of this innovation, we will also need commonsbased modes of governance, thus requiring us to thoroughly consider the relation between innovation and the commons. As Duvick notes, an advantage of public breeding organizations is that they intentionally can allocate scarce genetic resources among farmers working in small and exceptional adaptation areas, not likely to be served by the private sector (Duvick 2009). However, in the case of hybrid diploid potato breeding, this can only occur if these organizations engage in a collective effort to produce well-developed and publicly available diploid parental lines. Interestingly, these views and concerns also resonate in the earlier mentioned international opinion statement by public and private sector scientists. The authors of the statement point out that "instead of expecting each existing cultivar development program to initiate a diploid breeding program, another option is to plan a transition from the polyploid to the diploid breeding system as a global community and dedicate some programs, perhaps government programs and/or private companies, entirely to develop the diploid system" (Jansky et al. 2016, p. 1416).

The implication is that, if we would like hybrid potato breeding to be responsive to the major societal challenges addressed by the SDGs, we need to think about scenarios in which potato genetic resources remain to be governed as commons. One possible scenario is the establishment of hybrid breeding consortia, in which parental lines are developed and maintained in the public domain as the core genetic resources for hybrid breeding programs, where companies have the responsibility for crossing the parents, registering and marketing hybrid varieties. This scenario has been put into practice for a variety of hybrid crops in other sectors. Private sector members of such consortia pay an annual fee to get access to improved lines, while these lines are available for free to public sector institutions for further improvement (López-Noriega et al. 2012). Such consortia may also involve farmers' organizations and cooperatives (Gowda et al. 2009).

Another scenario is based on the concept of participatory breeding, which already has a long and well-documented history, and has been recognized for increasing the value of local genetic resources for smallholder farmers and conserving crop genetic diversity for future breeding ( $\mathrm{Li}$ et al. 2014; Almekinders et al. 2008; Westengen and Winge 2020). An inspiring and rare case of participatory hybrid breeding has been described for maize, where public sector breeders recognized that locally adapted landraces and farmer-improved maize varieties were a promising base for further hybrid improvement (Li et al. 2013; Song et al. 2016). By close collaboration with the local farmers, the breeders were able to understand the complex agroecological and socioeconomic conditions under which farmers had to work. Considering the farmers' trait and landrace preferences, the breeders started a program of hybrid breeding, whereby farmers were invited to evaluate and select their most preferred crosses. Under an Access and Benefit Sharing agreement, the breeders shared with the farmers the finally selected seeds and inbred-lines for community seed production, while the seeds were also certified and released for wider exploitation by a commercial seed company.

In both scenarios discussed above we see how particular socio-technical constellations for hybrid potato breeding may soften the potential tension between corporatebased and commons-based modes of governance of genetic resources, and could stimulate innovation in a way that is more responsive to the challenges of food security, sustainability and climate change. In their opinion statement Jansky et al. (2016) conclude with a call to leaders of public and private organizations to come together to explore the implications of hybrid diploid breeding as a radical and exciting new strategy to transform the potato industry. We believe that the co-production perspective on innovation and the commons developed here, helps to shed light on what exactly is at stake regarding the availability and accessibility of potato genetic resources.

\section{Conclusion}

Contrary to conventional accounts of the commons that treat technological innovation as an exogenous factor, we have argued that technological innovation can better be 
understood as an endogenous factor intertwined with governance, accessibility, and excludability of the commons. We have proposed the perspective of co-production as a fruitful way to understand the interaction between technological innovation and the commons. This has important implications for studying the governance of potato genetic resources as commons. First, from our co-production perspective, both the resources itself and the institutions that govern them should be understood as part of socio-technical constellations. This has already been hinted at in the literature about plant genetic resources mentioned before, in which these resources are considered as a 'new commons' in the context of changing technologies available for unlocking genetic material (Halewood 2013; Halewood et al. 2018). The governance of a resource as commons is thus partly mediated by technological innovations. In this respect our approach differs from conventional accounts of the commons which provide primacy to the nature of resources and the institutions that govern them apart from technologies (i.e. as exogenous variables).

In our perspective, innovation is not merely affecting the commons, but commons conversely also affect innovation. Our understanding of science and technology as part of socio-technical constellations implies that technological innovations developed by actors belonging to a community of users that govern resources according to their own rules and norms, will also themselves be mediated by the characteristics of the commons. From this perspective, innovation is not an external factor affecting an otherwise non-technological commons, nor is it just a knowledge common, but should rather be understood as a shift from one socio-technical constellation of a commons to another one. Co-production should hence be interpreted as an analytical framework that is useful in drawing attention to the different ways in which innovation, commons, and governance interact. It is such a framework, so we argue in this article, that allows for better understanding the relation between innovation and the commons.

Acknowledgment This article is a result of the research project Responsible Innovation in Dutch Potato Breeding (MVI-14-007), funded by the Dutch Research Council (NWO), which falls under the responsibility of the Dutch Ministry of Education, Culture and Science. Additional funding came from the Solynta Company (Wageningen) and the Kramp Group BV (Varsseveld), the Netherlands. We would like to thank all the interviewees and all others that have provided information and feedback on the topic of this paper, especially Pim Lindhout and Michiel de Vries from the Solynta Company, Niels Louwaars from the plant breeders' sector organization Plantum, the members of the valorisation panel of the NWO project, and our colleagues in the project team.

Open Access This article is licensed under a Creative Commons Attribution 4.0 International License, which permits use, sharing, adaptation, distribution and reproduction in any medium or format, as long as you give appropriate credit to the original author(s) and the source, provide a link to the Creative Commons licence, and indicate if changes were made. The images or other third party material in this article are included in the article's Creative Commons licence, unless indicated otherwise in a credit line to the material. If material is not included in the article's Creative Commons licence and your intended use is not permitted by statutory regulation or exceeds the permitted use, you will need to obtain permission directly from the copyright holder. To view a copy of this licence, visit http://creativecommons.org/licenses/by/4.0/.

\section{References}

Agentschap, NL. 2011. Het kwekersrecht in Nederland. Bescherming van plantenrassen. https://www.rvo.nl/sites/default/files/bijlagen/ Factsheet-kwekersrecht_0.pdf. Accessed 16 October 2019.

Allen, R.C. 1983. Collective invention. Journal of Economic Behavior \& Organization 4 (1): 1-24.

Almekinders, C.J.M., S. Humphries, and A. von Lossau. 2008. The effectiveness of participatory plant breeding as a tool to capitalize on agrobiodiversity in developing countries. Biodiversity 9 (1 \& 2): 41-44.

Almekinders, C.J.M., L. Mertens, J.P. van Loon, and E.T. Lammerts van Bueren. 2014. Potato breeding in the Netherlands: a successful participatory model with collaboration between farmers and commercial breeders. Food Security 6 (4): 515-524.

Almekinders, C.J.M., S. Walsh, K.S. Jacobsen, J.L. Andrade-Piedra, M.A. McEwan, S. de Haan, L. Kumar, and C. Staver. 2019. Why interventions in the seed systems of roots, tubers and bananas crops do not reach their full potential. Food Security 11 (1): 23-42.

Aubry, S. 2019. The future of digital sequence information for plant genetic resources for food and agriculture. Frontiers in plant science 10 , article 1046

Bethke, P.C., D.A. Halterman, and S.H. Jansky. 2019. Potato germplasm enhancement enters the genomics era. Agronomy 9 (10): 575.

Berge, E., and E. Kranakis. 2011. Technology-dependent commons: The radio spectrum. International Journal of the Commons 5 (1): 86-91.

Beumer, K., and R. Edelenbosch. 2019. Hybrid potato breeding: A framework for mapping contested socio-technical futures. Futures 109: 227-239.

Borowiak, C. 2004. Farmers' rights: Intellectual property regimes and the struggle over seeds. Politics \& Society 32 (4): 511-543.

Bollier, D. 2014. The commons as a template for transformation. Great Transformation Initiative. https://greattransition.org/publication/ the-commons-as-a-template-for-transformation. Accessed 16 October 2019.

Bonny, S. 2017. Corporate concentration and technological change in the global seed industry. Sustainability 9 (9): 1632.

Borup, M., N. Brown, K. Konrad, and H. Van Lente. 2006. The sociology of expectations in science and technology. Technology Analysis \& Strategic Management 18 (3-4): 285-298.

Brown, J., and P.D.S. Caligari. 2008. An introduction to plant breeding. New York: Wiley.

Brown, N., and M. Michael. 2003. A sociology of expectations: Retrospecting prospects and prospecting retrospects. Technology Analysis \& Strategic Management 15 (1): 3-18.

Byerlee, D., and H.J. Dubin. 2010. Crop improvement in the CGIAR as a global success story of open access and international collaboration. International Journal of the Commons 4 (1): 452-480.

CGIAR Generation Challenge Programme. https://www.generation cp.org. Accessed 26 July 2020. 
De Jonge, B. 2008. Between sharing and protecting: public research on genetic resources in the year of the potato. Genomics, Society and Policy 4 (3): 10-25.

Dedeurwaerdere, T. 2012. Design principles of successful genetic resource commons for food and agriculture. International Journal of Ecological Economics \& Statistics 26 (3): 31-46.

Dedeurwaerdere, T. 2013. Institutionalizing global genetic resource commons for food and agriculture. In Crop genetic resources as a global commons. Challenges in international law and governance. edited by Michael Halewood, Isabel López Noriega and Selim Louafi, 369-39. Oxford, UK: Routledge.

Deibel, E. 2013. Open Variety Rights: Rethinking the Commodification of Plants. Journal of Agrarian Change 13 (2): 282-309.

Duvick, D.N. 2009. Hybrid breeding. In Plant breeding and farmer participation, ed. Salvatore Ceccarelli, Elcio P. Guimarães, and Eva Weltzien, 229-258. Rome: FAO.

European Patent Office. 2017. EPO clarifies practices in the area of plant and animal patents. https://www.epo.org/news-issues/ news/2017/20170629.html. Accessed 30 October 2019.

Food and Agriculture Organization of the United Nations (FAO). 2015. FAO statistical databases. [database].

Frischmann, B.M., M.J. Madison, and K.J. Strandburg. 2014. Governing knowledge commons. Oxford: Oxford University Press.

Galluzzi, G., M. Halewood, I. López Noriega, and R. Vernooy. 2016. Twenty-five years of international exchanges of plant genetic resources facilitated by the CGIAR genebanks: A case study on global interdependence. Biodiversity and Conservation 25 (8): 1421-1446.

Gildemacher, P.R., W. Kaguongo, O. Ortiz, A. Tesfaye, G. Woldegiorgis, W.W. Wagoire, R. Kakuhenzire, P.M. Kinyae, M. Nyongesa, P.C. Struik, and C. Leeuwis. 2009. Improving potato production in Kenya, Uganda and Ethiopia: A system diagnosis. Potato Research 52: 173-205.

Gowda, C.L.L., P. Verma, K.N. Rai, B.V.S. Reddy and K.B. Saxena. 2009. Private sector partnering on crops for the poorest of the poor. Paper prepared for presentation at the "World Food Security: Can Private Sector R\&D Feed the Poor?" conference conducted by the Crawford Fund for International Agricultural Research, Parliament House, Canberra, Australia, October 27-28, 2009.

Halewood, M. 2013. What kind of goods are plant genetic resources for food and agriculture? Towards the identification and development of a new global commons. International Journal for the Commons 7 (2): 278-312.

Halewood, M., I. López Noriega, and S. Louafi. 2013. Crop genetic resources as a global commons. Challenges in international law and governance. New York: Routledge.

Halewood, M., et al. 2018. Plant genetic resources for food and agriculture: Opportunities and challenges emerging from the science and information technology revolution. New Phytologist 217: 1407-1419.

Hardin, G. 1968. The tragedy of the commons. The population problem has no technical solution; it requires a fundamental extension in morality. Science 162 (3859): 1243-1248.

Harvey, M., and A. McMeekin. 2010. Public or private economies of knowledge: The economics of diffusion and appropriation of bioinformatics tools. International Journal of the Commons 4 (1): 481-506.

Haverkort, A.J., P.C. Struik, R.G.F. Visser, and E. Jacobsen. 2009. Applied biotechnology to combat late blight in potato caused by Phytophthora Infestans. Potato Research 52 (3): 249-264.

Haverkort, A.J., and P.C. Struik. 2015. Yield levels of potato crops: Recent achievements and future prospects. Field Crops Research 182: 76-85.

Haverkort, A.J., and A. Verhagen. 2008. Climate change and its repercussions for the potato supply chain. Potato Research 51: 223-237.
Hess, C. and E. Ostrom. 2006. Understanding knowledge as a commons. From theory to practice. Cambridge, MA.: MIT Press.

Hosaka, K., and R.E. Hanneman. 1998. Genetics of self-compatibility in a self-incompatible wild wild diploid potato species Solanum chacoense. Euphytica 99 (3): 191-197.

Jansky, S.H., et al. 2016. Reinventing potato as a diploid inbred linebased crop. Crop Science 56 (4): 1412-1422.

Jasanoff, S. 2004. States of knowledge. The co-production of science and social order. London: Routlegde.

Jefferson, O.A., D. Köllhofer, T.H. Ehrich, and R.A. Jefferson. 2015. The ownership question of plant gene and genome intellectual properties. Nature Biotechnology 33 (11): 1138-1143.

Kloppenburg, J.R. 2004. First the seed. The political economy of plant biotechnology. Madison: University of Wisconsin Press.

van Laerhoven, F., and E. Ostrom. 2007. Traditions and trends in the study of the commons. International Journal of the Commons 1 (1): 3-28.

Laird, S.A., and R.P. Wynberg. 2018. A fact-finding and scoping study on digital sequence information on genetic resources in the context of the Convention on Biological Diversity and the Nagoya Protocol. Montreal: CBD.

Lammerts van Bueren, E.T., M. Tiemens-Hulscher, and P.C. Struik. 2008. Cisgenesis does not solve the late blight problem of organic potato production: Alternative breeding strategies. Potato Research 51: 89-99.

Lammerts van Bueren, E.T. and R. Hutten. 2012. Bioimpuls gaat lange weg, met zijpaden. Ekoland. https://edepot.wur.nl/249243. Accessed 16 October 2019.

Lammerts van Bueren, E. T. and J.P. van Loon. 2011. De praktijk van de kleine kwekers in de aardappelveredeling in Nederland. COGEM report nr. CGM 2011-05. Bilthoven: COGEM

Li, J., E.T. Lammerts van Bueren, K. Huang, L. Qin, and Y. Song. 2013. The potential of participatory hybrid breeding. International Journal of Agricultural Sustainability 11 (3): 234-251.

Li, J., E.T. Lammerts van Bueren, C. Leeuwis, and J. Jiggins. 2014. Expressing the public value of plant genetic resources by organising novel relationships: The contribution of selected participatory plant breeding and market-based arrangements. Journal of Rural Studies 36: 182-196.

Lindhout, P., D. Meijer, T. Schotte, R.C.B. Hutten, R.G.F. Visser, and H.J. van Eck. 2011. Towards F1 hybrid seed potato breeding. Potato Research 54 (4): 301-312.

Lindhout, P., M. de Vries, M. ter Maat, Y. Su, M. Viquez-Zamora, and S. van Heusden. 2018. Hybrid potato breeding for improved varieties. In Achieving sustainable cultivation of potatoes Volume 1 Breeding, nutritional and sensory quality, ed. Gefu Wang-Pruski, 99-122. Cambridge, UK: Burleigh Dodds Science Publishing Limited.

López-Noriega, I., G. Galluzzi, M. Halewood, R. Vernooy, E. Bertacchini, D. Gauchan and E. Welch. 2012. Flows under stress: Availability of plant genetic resources in times of climate and policy change. Working paper 18. Copenhagen: CCAFS. https://cgspa ce.cgiar.org/handle/10568/21225. Accessed 31 October 2019.

Louwaars, N.P. 2018. Plant breeding and diversity: A troubled relationship? Euphytica 214: 114.

Mirowski, P. 2011. Science-mart. Privatizing American science. Cambridge, MA.: Harvard University Press.

Ostrom, E. 1990. Governing the commons. The evolution of institutions for collective action. Cambridge: Cambridge University Press.

Ostrom, E., J. Burger, C.B. Field, R.B. Norgaard, and D. Policansky. 1999. Revisiting the commons: Local lessons, global challenges. Science 284 (5412): 278-282.

Ostrom, E. 2002. Common-pool resources and institutions: Toward a revised theory. In Handbook of agricultural economics, ed. Bruce L. Gardner and Gordon C. Rausser, 1315-1339. Amsterdam: Elsevier. 
Ostrom, E. 2009. Beyond markets and states: polycentric governance of complex economic systems. Nobel Prize Lecture. https://www. nobelprize.org/uploads/2018/06/ostrom_lecture.pdf. Accessed 16 October 2019.

PGSC. 2011. (Potato Genetic Sequencing Consortium). Genome sequence and analysis of the tuber crop potato. Nature 475: 189-195.

POTAREI. 2015-2020. https://www.nwo-mvi.nl/project/responsibl e-innovation-dutch-potato-breeding.

Rabobank. 2016. Thema-update: pootaardappelsector. Rabobank Cijfers \& trends. https://docplayer.n1/27000396-Rabobank-cijfe rs-trends-grenzen-opzoeken-thema-update-pootaardappelsector. html. Accessed 16 October 2019.

Radin, J. and E. Kowal. 2017. Cryopolitics. Frozen life in a melting world. Cambridge, MA: MIT Press.

Scott, D. and D. Berry. 2016. Genetic resources in the age of the Nagoya Protocol and gene/genome synthesis. Report and analysis of an interdisciplinary workshop. The University of Edinburgh. https://static1.squarespace.com/static/584d41b3f5e2310b396c d953/t/5c70382824a6943d4f1c8581/1550858285283/Nagoy a_workshop_report_publishable.pdf. Accessed 30 October 2019.

Smith, S., S.H. Lence, D.J. Hayes, J. Alston, and E. Corona. 2016. Elements of intellectual property protection in plant breeding and biotechnology: Interactions and outcomes. Crop Science 56: 1401-1401.

Solynta. 2016. Paradigm shift. https://web.archive.org/web/20161 031150314/https://www.solynta.com/hybrid-potato-breeding/ paradigm-shift. Accessed 30 October 2019.

Solynta. 2019. Complex potato genome further unveiled. https://solyn ta.com/index.php/2019/09/19/complex-potato-genome-furtherunveiled/. Accessed 30 October 2019.

Song, Y., Z. Yanyan, X. Song and R. Vernooy. 2016. Access and benefit sharing in participatory plant breeding in Southwest China. Farming matters: Access and benefit sharing of genetic resources, 18-23 ILEIA. https://www.fao.org/agroecology/database/detail/ en/c/470661/. Accessed 31 October 2019.

Stern, P.C., T. Dietz, and E. Ostrom. 2002. Research on the commons: Lessons for environmental resource managers. Environmental Practice 4 (2): 61-64.

Stern, P.C. 2011. Design principles for global commons: Natural resources and emerging technologies. International Journal of the Commons 5 (2): 213-232.

Stokstad, E. 2019. The new potato. Breeders seek a breakthrough to help farmers facing an uncertain future. Science 363 (6427): 574-577.
Terranova, T. 2015. Introduction to Eurocrisis, neoliberalism and the common. Theory, Culture \& Society 32 (7-8): 5-23.

Tönjes, J. 2016. Plantum: We zijn er nog niet met octrooi en kwekersrecht. Akkerwijzer. https://www.akkerwijzer.nl/artikel/118620-plant um-we-zijn-er-nog-niet-met-octrooi-en-kwekersrecht/. Accessed 16 October 2019.

UPOV. 1991. [International convention for the protection of new varieties of plants]. https://www.upov.int//upovlex/en/convention s/1991/content.html. Assessed 21 April 2020.

van Dijk, L., R. Edelenbosch and K. Beumer. 2016. Potato breeding in the Netherlands. Report for the Potarei project.

Visser, B., S.B. Brush, G.A. Aistara, R. Andersen, M. Jäger, G. Nemogá, M. Padmanabhan, and S.G. Sherwood. 2019. The governance of agrobiodiversity. In Agrobiodiversity: Integrating knowledge for a sustainable future, ed. Karl S. Zimmerer and Stef de Haan, 283-305. Cambridge, MA: MIT Press.

Welch, E.W., M. Bagley, T. Kuiken and S. Louafi. 2017. Potential implications of new synthetic biology and genomic research trajectories on the International Treaty for Plant Genetic Resources for Food and Agriculture. Scoping report. Rome: FAO.

Westengen, O.T., and T. Winge. 2020. Farmers and plant breeding: Current approaches and perspectives. Abingdon/New York: Routledge.

WWR. 2012 [Wetenschappelijke Raad voor het Regeringsbeleid]. Publieke zaken in een marktsamenleving. The Hague: WRR.

Wormbs, N. 2011. Technology-dependent commons: The example of frequency spectrum for broadcasting in Europe in the 1920s. International Journal of the Commons 5 (1): 92-109.

Publisher's Note Springer Nature remains neutral with regard to jurisdictional claims in published maps and institutional affiliations.

Koen Beumer is an assistant professor at the Copernicus Institute of Sustainable Development, Utrecht University.

Dirk Stemerding is an independent researcher in biotechnology and society, with a strong interest in responsible research and innovation.

Jac. A. A. Swart is an associate professor at the Science and Society Group, University of Groningen. 